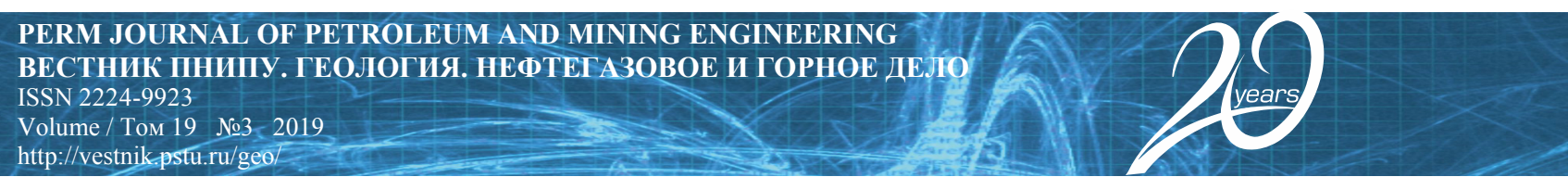

UDC 622.276:552.578.2.061.4

Article / Статья

(C) PNRPU / ПНИПУ, 2019

\title{
PETROPHYSICAL ASPECTS OF DEEP RESERVOIRS IN THE ABSHERON AND BAKU ARCHIPELAGOS
}

\section{Vaqif Sh. Gurbanov, Latif A. Sultanov ${ }^{1}$}

Azerbaijan National Academy of Sciences Institute Oil and Gas (9 F. Amirova st., Baku, AZ1001, Republic of Azerbaijan)

${ }^{1}$ Azerbaijan State Oil and Industry University, Baku, Azerbaijan (20 Azadlyg av., Baku, AZ1010, Republic of Azerbaijan)

\section{ПЕТРОФИЗИЧЕСКИЕ ОСОБЕННОСТИ ГЛУБОКОЗАЛЕГАЮЩИХ КОЛЛЕКТОРОВ АПШЕРОНСКОГО И БАКИНСКОГО АРХИПЕЛАГОВ}

\section{В.Ш. Гурбанов, Л.А. Султанов}

Национальная академия наук Азербайджана. Институт нефти и газа (AZ1001, Азербайджан, г. Баку, ул. Ф. Амирова, 9) ${ }_{1}^{1}$ Азербайджанский государственный университет нефти и промышленности (AZ1010, Азербайджан, г. Баку, пр. Азадлыг, 20) Received / Получена: 07.05.2019. Accepted / Принята: 01.08.2019. Published / Опубликована: 27.09.2019

\section{Keywords:}

rock, suite, porosity, depth, well, density, petrophysics, the MesoCenozoic Era, horizon, drilling, geophysics, oil and gas accumulation, reservoir, carbonate content, P-wave velocity.
Based on the recent information about oil and gas production potential in Azerbaijan, a geological and geophysical assessment of deep formations has been made. Scientific criteria have been prepared in order to use them as a basis for new assessment of deep formations has been made. Scientific criteria have been prepared in order to use them as a basis for new
researches. It has been highlighted that the main oil and gas fields are associated with the South Caspian and Kura basins, researches. It has been highlighted that the main oil and gas fields are associated with the South Caspian and Kura basins,
which were subjected to intense sinking during the Mesozoic Era. The high production potential of the central part and deep formations has not been sufficiently shown in terms of quality and quantity.

It is known that the exploration, production and assessment of oil and gas field potential strongly depend on the information collected about petrophysical parameters of the formation. Researches shall be conducted concerning the oil and gas regions in the Absheron and Baku archipelagos, where Mesozoic and Cenozoic sediments are widely spread.

Various geological, geophysical and physical aspects that had been influencing the reservoir potential of oil, gas, and gas condensate fields in that region have been studied. The conducted researches demonstrate that there is a thin layer of Pliocene anthropogenic deposits of 100 to $200 \mathrm{~m}$ in the paleoprofiles formed along the Kurdakhan - Shah Deniz offshore field in the anthropogenic deposits of 100 to $200 \mathrm{~m}$ in the paleoprofiles formed along the Kurdakhan - Shah Deniz offshore field in the
northwest. The thickness increases towards Kum Adasi up to $3600 \mathrm{~m}$ and reaches $6000 \mathrm{~m}$ in Shah Deniz. Along the edges of northwest. The thickness increases towards Kum Adasi up to $3600 \mathrm{~m}$ and reaches $6000 \mathrm{~m}$ in Shah Deniz. Along the edges of
the synclinal folds, the thickness of the abovementioned deposits reaches $3000 \mathrm{~m}$ in the northwest and about $10,000 \mathrm{~m}$ in Shah Deniz. Therefore, without sufficient knowledge about reservoir properties of the layer, it is impossible to assess the hydrocarbon accumulations and production volumes and change the exploration direction. In addition to geological and geophysical researches conducted in the area, lithologic, petrographic and reservoir properties have been studied in order to identify changes in the correspondence of carbon content, porosity, permeability, density, grain size distribution and sound wave velocity along the area to the properties of the abovementioned layer. For this reason, a table with the field reservoir properties has been prepared. It contains upper, intermediate and lower boundaries of physical characteristics, analyses the reservoir property interdependences and determines the formation depth and other physical aspects.

The researches show that physical characteristics of coeval and homonymous rock change due to geological and physical processes and lead to different results. The reservoir characteristics of productive strata have been studied. A table has been prepared to show physical parameters of the area depending on time and place and to display different types and frequency of geological characteristics pertaining to the reservoir rock.

Недавно на основе сведений о перспективах добычи нефти и газа в Азербайджане была проведена геологическая и геофизическая оценка глубоких слоев. Были подготовлены научные критерии, которые могут быть основанием для будущих исследований. Отмечено, что основные месторождения нефти и газа связаны с Южным Каспием и Курским бассейном, которые подвергались интенсивному углублению во время мезозойской эры. Высокая перспективность центральной части и глубоких слоев не была количественно и численно выражена должным образом.

Известно, что разведка, добыча и оценка потенциала нефтяных и газовых месторождений сильно зависят от собранной Информации о петрофизических характеристиках слоев. Исследования должны проводиться в нефтяных и газовых информации о петрофизических характеристиках слоев. Исследования должны проводиться в нефтяных и газов регионах Апшеронского и Бакинского архипелагов, где отложения мезозоя и кайнозоя широко распространены. нефтяных, газовых и газоконденсатных месторождений в данном районе. Проведенные исследования показывают, что в палеопрофилях, образованных вдоль Кюрдакхан-Шах-Дениз шельфового месторождения Шах-Дениз на северо-западе, были залежи плиоцен-антропогенных скоплений тонким слоем - от 100 до 200 м. Толщина увеличивается к Кум адасы до 3600 м и в Шах-Денизе до 6000 м. По краям синклинальных складок толшина упомянутых скоплений достигает 3000 м на

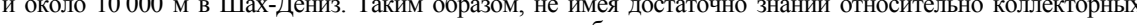
обследования. Помимо геолого-геофизических исследований, проведенных в этой области, были изучены литологическопетрографические и коллекторные характеристики для определения изменений соответствия вдоль области содержания углерода, пористости, проницаемости, плотности, гранулярного состава и скорости звуковых волн вышеупомянутой страты. Соответственно, была составлена таблица, отражающая коллекторские характеристики месторождения, в которой были указаны верхние, средние и нижние границы физических характеристик; проанализированы зависимости коллекторских характеристик друг от друга, определены глубина залежей и другие физические аспекты.

Исследования показывают, что физические особенности одновозрастных и одноименных пород изменяются в результате геолого-физических процессов, приводя к разным результатам. Были изучены коллекторские свойства пород геолого-физических процессов, приводя к разным результатам. Были изучены коллекторские свойства пород
продуктивной толщи. Создана таблица, отражающая физические свойства данной площади во времени и пространстве, а также различные типы геологических особенностей пород-коллекторов и закономерность их распространения.

Гурбанов Вагиф Шыхы оглы - доктор геолого-минералогических наук, профессор, заместитель директора по научным вопросам (тел.: +994 502140969 , e-mail: vagifqurbanov@mail.ru). Контактное лицо для переписки.

Султанов Латиф Агамирза оглы - научный сотрудник лаборатории физических свойств горных пород месторождений полезных ископаемых (тел.:+994 5032797 01, e-mail: latif.sultan@mail.ru).

Vaqif Sh. Gurbanov (Author ID in Scopus: 26028826000) - Doctor of Geology and Mineralogy, Professor, Deputy Director for Scientific Affairs of the Institute of Oil and Gas (tel.: +994 5021409 69, e-mail: vagifqurbanov@mail.ru). The contact person for correspondence.

Latif A. Sultanov (Author ID in Scopus: 57209321385) - Research fellow, Laboratory of Physical Properties of Mineral Deposits Rocks (tel.:+994 50 3279701 , e-mail: latif.sultan@mail.ru). 


\section{Introduction}

The reservoir properties of rock are crucially important to study when determining the formation potential in terms of oil and gas content and estimating the reserves at proven fields. In addition to this, the oil and gas industry currently demand to update and intensify the development processes applied at oil and gas fields.

For this reason, the geological and geophysical rock characteristics influencing reservoir potential of the deposits containing oil, gas and gas condensate accumulations of the Meso-Cenozoic Era have been studied.

\section{Deep Reservoirs in the Absheron Archipelago}

The Absheron archipelago features the Neft Dashlary fold located in the near-axial zone of the Absheron-Prebalkhan mega-arch structure and stretched in the general Caucasian direction. The fold is complicated by two longitudinal and multiple transversal fractures.

The longitudinal fractures represent a wide area of disjunctive dislocations built by strongly broken brecciate deposits of the Oligocene-Miocene Era. In the southeastern part of the fold, at the intersection of longitudinal and transversal fractures, there is a mud volcano. There, the sea bottom is characterized by multiple springs continuously emitting oil and gas.

It is known that the oil and gas potential of rock depends on its petrophysical characteristics. To determine the petrophysical characteristics in deep layers, the carbonate content, porosity, permeability, density, grain size distribution and P-wave propagation velocity have been assessed in the rock samples taken from exploratory wells drilled in the area of Neft Dashlary. Moreover, we have determined the average values of sample physical characteristics and the dependence of reservoir properties on the formation depth and rock physical parameters. The petrophysical and reservoir properties of the rock have been summarized in a table prepared by the authors (Table 1) [1-12].

The Neft Dashlary field is characterized by anticline, lithologic, and tectonic petroleum traps.

The local argillaceous rock has a density of $2.20-2.48 \mathrm{~g} / \mathrm{cm}^{3}$, a porosity of $8.3-17 \%$ (in some cases, it reaches $25 \%$ ), and an ultrasonic wave propagation of $2150-2200 \mathrm{~m} / \mathrm{s}$. In siltstone, the density varies within $2.13-2.60 \mathrm{~g} / \mathrm{cm}^{3}$, the porosity is $15-28 \%$, and the ultrasonic wave propagation varies within 1300 $2200 \mathrm{~m} / \mathrm{s}$. In sandstone, the density ranges from 2.00 to $2.50 \mathrm{~g} / \mathrm{cm}^{3}$, and the porosity is $7.2-22.0 \%$. In all types of rock, the ultrasonic wave propagation varies within $850-2800 \mathrm{~m} / \mathrm{s}$ depending on the lithological composition. In the limestone clay comprising the productive strata, the density is $2.02-2.59 \mathrm{~g} / \mathrm{cm}^{3}$, the porosity is $8.5-30 \%$, and the ultrasonic wave propagation is $2100-3500 \mathrm{~m} / \mathrm{s}$.

Grain-type deposits in the productive strata of the Neft Dashlary area are mainly represented by silt facies, i.e. the grain size varies from 0.1 to $0.01 \mathrm{~mm}$. This indicates silt prevalence over other types of facies in the section.

To understand how the reservoir properties change when the productive strata deposits are deepening, the change limits for the correlated physical parameters have been studied. Thus, Table 1 shows that the rock carbonate content varies from 5.27 to $24.6 \%$, and the permeability varies from 1.3 to $214.9 \cdot 10^{15} \mathrm{~m}^{2} \mu \mathrm{m}^{2}$, while the porosity is in the range of $9.02-21.4 \%$.

According to Table 1, we can assume that the changes in physical characteristics of the productive strata rock in the Neft Dashlary area are related to the quantified amount of rock types, rock variety, rock mineralogical composition and tectonic conditions.

The Chilov Island field represents a sloping fold that extends from the northwest to the southeast for $10 \mathrm{~km}$ having a width of up to $4 \mathrm{~km}$ and steep angle wings (up to $55-80^{\circ}$ ). The fold crest is water-worn till the diatomaceous suite and is complicated by a thrust fault, the outlet of which is seen at the bottom of the sea almost for $15 \mathrm{~km}$. The vertical displacement amplitude is $500 \mathrm{~m}$. The fold is also complicated by seven transversal and two longitudinal fractures having vertical displacement amplitude of up to $250 \mathrm{~m}$. It has a complex structure and is split into 10 blocks by several longitudinal and transversal irregularities [13-23].

The deposits in the geological structure of the Chilov Island field are studied from the modern layers until the diatomaceous suite inclusive. The latter is represented by a frequent alternation of clay minerals, marlstone and siltstone. Its penetrated depth is $290 \mathrm{~m}$. The Pontian deposits mainly consist of clay minerals.

Table 1 shows a significant change in the rock permeability within the studied depths, while the change in the porosity is slight. 
In some cases, the changes in rock petrophysical characteristics generate some irregularities. This is seen on the curves visualizing the changes in the rock reservoir properties (Table 2).

In addition, we have studied the relation between the porosity and carbonate content in the rock of the Absheron archipelago areas. As a result, a clear reversible relation between the carbonate content and porosity of the rock has been established.

According to tables 1 and 2, the porosity and carbonate content change step-wise. In some cases, the porosity exceeds $20 \%$. The maximum porosity is $15.7 \%$ in Gyurgyan Deniz, and 18.0 \% in Chilov Island [23-28].

Therefore, in three areas of the Absheron archipelago, studying petrophysical properties of the productive strata reservoirs allowed us to determine the main parameters and track their changes depending on the depth.
The conducted analysis of petrophysical characteristics can be approximated to the neighbouring areas based on their paleogeographic similarity and structural-and-tectonic processes that formed local elevations.

The analysed lithologic and petrographic properties of the deposits in the studied areas and reservoir properties of the rock samples allow us to the predict oil and gas occurrence.

\section{Deep Reservoirs of the Baku Archipelago}

We have studied petrophysical characteristics of the rock constituting the northern structures of the Baku archipelago (Sangachal-Deniz, Duvanny-Deniz and Bulla-Deniz), where the productive strata deposits are thick.

Table 1

The petrophysical characteristics of the productive strata rock by its depth in the areas of the Absheron archipelago

\begin{tabular}{|c|c|c|c|c|c|c|}
\hline $\begin{array}{c}\text { Depth } \\
\text { interval, } \mathrm{m}\end{array}$ & Lithology & $\begin{array}{l}\text { Carbonate } \\
\text { content, } \%\end{array}$ & Porosity, $\%$ & $\begin{array}{c}\text { Permeability, } \\
10^{-15} \mathrm{~m}^{2}\end{array}$ & $\begin{array}{l}\text { Density, } \\
\sigma, \mathrm{g} / \mathrm{cm}^{3}\end{array}$ & $\begin{array}{c}\text { Elastic wave } \\
\text { propagation } \\
\text { velocity } \\
V, \mathrm{~m} / \mathrm{s}\end{array}$ \\
\hline $430-480$ & $\begin{array}{l}\text { Sandy-argillaceous } \\
\text { siltstone }\end{array}$ & $\frac{8,3-12,8}{9,7}$ & $\frac{11,6-20,1}{16,3}$ & $\frac{28,5-79,4}{59,7}$ & $\frac{2,42-2,50}{2,45}$ & $\frac{2200-2600}{2400}$ \\
\hline $480-600$ & Silty clay & $\frac{4,9-26,8}{19,14}$ & $\frac{12,4-17,0}{11,0}$ & $\frac{2,6-8,1}{5,35}$ & $\frac{2,36-2.56}{2,50}$ & $\frac{2000-3100}{2650}$ \\
\hline $640-690$ & $\begin{array}{l}\text { Argillo-arenaceous } \\
\text { siltstone }\end{array}$ & $\frac{5,8-12,4}{7,53}$ & $\frac{11,0-33,6}{16,92}$ & $\frac{0,1-95,7}{40,68}$ & $\frac{1,6-2,34}{2,20}$ & $\frac{1700-2400}{1980}$ \\
\hline $690-930$ & $\begin{array}{c}\text { Argillo-arenaceous } \\
\text { siltstone }\end{array}$ & $\frac{8,9-9,9}{9,37}$ & $\frac{19,5-22,9}{21,4}$ & $\frac{0,1-95,7}{2,20}$ & $\frac{2,01-2,10}{2,05}$ & $\frac{2400-2600}{2500}$ \\
\hline $930-940$ & $\begin{array}{c}\text { Sandy-argillaceous } \\
\text { siltstone }\end{array}$ & $\frac{8,2-9,4}{8,8}$ & $\frac{9,9-25,7}{15,5}$ & $\frac{1-3,5}{2,3}$ & $\frac{2,01-2,47}{2,37}$ & $\frac{2300-3200}{3000}$ \\
\hline $940-1130$ & Clayey siltstone & $\frac{4,5-6,0}{5,27}$ & $\frac{6,0-16,0}{9,57}$ & 214,9 & $\frac{2,37-2,67}{2,56}$ & $\frac{2500-3000}{2800}$ \\
\hline $1130-1400$ & $\begin{array}{l}\text { Argillo-arenaceous } \\
\text { siltstone }\end{array}$ & $\frac{23,4-25,8}{24,60}$ & $\frac{9,7-11,1}{10,40}$ & $\frac{2,25-6,23}{4,24}$ & $\frac{2,38-2,53}{2,44}$ & $\frac{2100-3200}{2580}$ \\
\hline $1500-1550$ & Clayey siltstone & $\frac{3,0-11,0}{7,0}$ & $\frac{12,6-14,9}{13,75}$ & $\frac{0,6-2,0}{1,3}$ & $\frac{2,40-2,47}{2,44}$ & $\frac{2300-2400}{2350}$ \\
\hline $1600-2050$ & Clayey siltstone & $\frac{3,8-15,7}{11,8}$ & $\frac{7,6-10,8}{9,02}$ & 56,9 & $\frac{2,47-2,56}{2,51}$ & $\frac{3500-3600}{3550}$ \\
\hline $2050-2200$ & $\begin{array}{c}\text { Sandy-argillaceous } \\
\text { siltstone }\end{array}$ & $\frac{4,1-14,6}{9,79}$ & $\frac{13,6-17,9}{14,8}$ & 12,5 & $\frac{2,36-2,43}{2,40}$ & 3150 \\
\hline $2200-2500$ & Clayey siltstone & $\frac{3,8-15,7}{11,8}$ & $\frac{7,6-10,8}{9,02}$ & 56,9 & $\frac{2,47-2,56}{2,51}$ & $\frac{3500-3600}{3550}$ \\
\hline $2550-3550$ & Clayey siltstone & $\frac{7,8-8,7}{8,1}$ & $\frac{8,5-10,0}{9,9}$ & 66,9 & $\frac{2,43-2,60}{2,56}$ & 3600 \\
\hline $3550-4600$ & $\begin{array}{l}\text { Argillo-arenaceous } \\
\text { siltstone }\end{array}$ & $\frac{2,8-10,8}{6,8}$ & $\frac{5,3-14,2}{9,57}$ & 60,5 & $\frac{2,58-2,64}{2,61}$ & 4000 \\
\hline
\end{tabular}

Note: here and in Table 2, the numerator indicates the minimum and maximum values, and the denominator indicates average values. 
The full thickness of the productive strata (3950 $4000 \mathrm{~m})$ was penetrated at the area of SangachalDeniz and in the northeastern part of other areas. At the crest and crest positions of Sangachal-Deniz and Duvanny-Deniz local elevations, the productive strata thickness is $2960-3600 \mathrm{~m}$.

The elevation of Sangachal-Deniz tectonically represents an asymmetric brachyaxial fold separated from the northwest Kyanizadag elevation by a long but not deep saddle. In the southeast productive strata, the plunge of the fold is seen in the terrain as a not deep and short saddle separating it from Duvanny elevation.

The rock constituting the Sangachal-Deniz and Duvanny-Deniz fields are studied employing deep drilling from modern to the Mesozoic layers inclusive. The productive strata crops out in the northern part of the elevation; in the near-axial zone it is water-worn to a depth of $750-800 \mathrm{~m}$. The lithological section of the rock is mainly represented by the alternating sand, sandstone and clay minerals. The maximum thickness of deposits in the productive strata revealed by the drilling is 3950 $4000 \mathrm{~m}$, and the minimum thickness is $3000 \mathrm{~m}$.

The deposits of the Akchagyl strata, Absheron strata and Quaternary strata participate in the area geological structure. Here, the productive strata have been penetrated till the top of the Kirmakinskaya suite. The Kirmakinskaya suite is mainly represented by clay minerals, sandstone and siltstone. In argillaceous rock, the density is $1.95-2.20 \mathrm{~g} / \mathrm{cm}^{3}$, the porosity is $7.5-25.5 \%$, the ultrasonic wave propagation varies within 1950-2300 $\mathrm{m} / \mathrm{s}$. In sandstone the density is $2.15-2.50 \mathrm{~g} / \mathrm{cm}^{3}$, and the ultrasonic wave propagation is $1200-3000 \mathrm{~m} / \mathrm{s}$. In siltstone, the density is $2.06-2.56 \mathrm{\Gamma} / \mathrm{cm}^{3}$, the porosity is $5.5-30 \%$, and the ultrasonic wave propagation is $1950-2800 \mathrm{~m} / \mathrm{s}$.

Table 2

The change in average values of physical parameters

pertaining to productive strata sedimentary rock at the Neft Dashlary field

\begin{tabular}{|c|c|c|c|c|c|c|}
\hline $\begin{array}{c}\text { Depth } \\
\text { interval, } \mathrm{m}\end{array}$ & Lithology & Carbonate content, $\%$ & Porosity, $\%$ & $\begin{array}{c}\text { Permeability, } \\
10^{-15} \mathrm{~m}^{2}\end{array}$ & $\begin{array}{l}\text { Density, } \\
\sigma, \mathrm{g} / \mathrm{cm}^{3},\end{array}$ & $\begin{array}{c}\text { Elastic wave propagation } \\
\text { velocity, } V, \mathrm{~m} / \mathrm{s}\end{array}$ \\
\hline & Sandy- & $\begin{array}{llll}0 & 10 & 20 & 30\end{array}$ & $\begin{array}{llll}0 & 10 & 20 & 30\end{array}$ & 0100200300 & $22,32,62,9$ & 180030004200 \\
\hline $430-480$ & $\begin{array}{l}\text { argillaceous } \\
\text { siltstone }\end{array}$ & $\rightarrow$ & 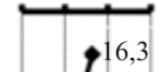 & 59,7 & & , \\
\hline $480-600$ & Silty clay & & & & & \\
\hline $640-690$ & $\begin{array}{l}\text { Argillo- } \\
\text { arenaceous } \\
\text { siltstone }\end{array}$ & & & & & \\
\hline $690-930$ & $\begin{array}{c}\text { Argillo- } \\
\text { arenaceous } \\
\text { siltstone }\end{array}$ & & & 40,68 & & \\
\hline $930-940$ & $\begin{array}{c}\text { Sandy- } \\
\text { argillaceous } \\
\text { siltstone }\end{array}$ & & & & & \\
\hline $940-1130$ & $\begin{array}{c}\text { Clayey } \\
\text { siltstone }\end{array}$ & & 9,57 & & & \\
\hline $1130-1400$ & $\begin{array}{c}\text { Argillo- } \\
\text { arenaceous } \\
\text { siltstone }\end{array}$ & & & & & \\
\hline $1500-1550$ & $\begin{array}{c}\text { Clayey } \\
\text { siltstone }\end{array}$ & & & & & \\
\hline $1600-2050$ & $\begin{array}{c}\text { Clayey } \\
\text { siltstone }\end{array}$ & 11,8 & 9,02 & 56.9 & & \\
\hline $2050-2200$ & $\begin{array}{c}\text { Sandy- } \\
\text { argillaceous } \\
\text { siltstone }\end{array}$ & & & 50,9 & & \\
\hline $2200-2500$ & $\begin{array}{c}\text { Clayey } \\
\text { siltstone }\end{array}$ & 11,8 & 9,02 & 56,9 & & \\
\hline $2550-3550$ & $\begin{array}{c}\text { Clayey } \\
\text { siltstone }\end{array}$ & 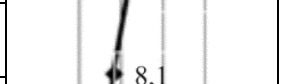 & & & & \\
\hline $3550-4600$ & $\begin{array}{c}\text { Argillo- } \\
\text { arenaceous } \\
\text { siltstone }\end{array}$ & 6,8 & 9,57 & $\int_{60,5}^{66,9}$ & & \\
\hline
\end{tabular}


The conducted researches let us assume that the changes in petrophysical and reservoir properties of the rock comprising the main assemblage of the object under investigation are related to the carbonate content, lithological heterogeneity, various density and tectonic conditions. This allowed us to establish a relationship between the carbonate content, porosity and permeability (Table 3 ).

Therefore, analysing the rock that forms the geological structure of Sangachal-Deniz, DuvannyDeniz and Bulla-Deniz, we compiled a table to show the rock petrophysical properties, including the reservoir properties, in the view of areas and sections. The dependence of the rock reservoir properties on its litho-physical properties has been studied.

The investigation results concerning the petrophysical parameters exhibited by the rock in particular areas of the Baku archipelago can be found below.
The petroleum and gas condensate fields of Sangachal-Deniz, Duvanny-Deniz and Hara-Zire Island are located in the north of the Baku archipelago and are included in one anticlinal zone; therefore, they can be regarded as an assemblage. In that place, the productive strata deposits penetrated by drilling have a maximum thickness of 3950$4000 \mathrm{~m}$ and a minimum thickness of $3000 \mathrm{~m}$. In the north of the Baku archipelago, in argillaceous deposits, the density is $2.26-2.50 \mathrm{~g} / \mathrm{cm}^{3}$, the porosity is $9.5-18 \%$ (in some cases it reaches $30 \%$ ), and the ultrasonic wave propagation is $2200-2300 \mathrm{~m} / \mathrm{s}$. In siltstone, the density is $2.16-2.63 \mathrm{~g} / \mathrm{cm}^{3}$, the porosity is $15-30 \%$, and the ultrasonic wave propagation velocity varies within $1500-2500 \mathrm{~m} / \mathrm{s}$. In sandstone, the density is $2.07-255 \mathrm{~g} / \mathrm{cm}^{3}$, and the porosity is $8.2-22.5 \%$. As in all other rock types, the ultrasonic wave propagation in sandstone depends on the mineralogical composition, cementing material, density and other factors.

Table 3

The petrophysical characteristics of the productive strata rock

by its depth in the areas of the Baku archipelago

\begin{tabular}{|c|c|c|c|c|c|c|c|c|c|}
\hline \multirow{2}{*}{$\begin{array}{c}\text { Interval, } \\
\mathrm{m}\end{array}$} & \multicolumn{4}{|c|}{ Particle size, $\mathrm{mm}$} & \multirow{2}{*}{$\begin{array}{c}\text { Carbonate } \\
\text { content } \\
\%\end{array}$} & \multirow{2}{*}{$\begin{array}{c}\text { Porosity, } \\
\%\end{array}$} & \multirow{2}{*}{$\begin{array}{c}\text { Permeability, } \\
10^{-15} \mathrm{~m}^{2}\end{array}$} & \multirow{2}{*}{$\begin{array}{l}\text { Density } \\
\sigma, \mathrm{g} / \mathrm{cm}^{3}\end{array}$} & \multirow{2}{*}{$\begin{array}{c}\text { Ultrasonic } \\
\text { wave } \\
\text { propagation } V, \\
\mathrm{~m} / \mathrm{s}\end{array}$} \\
\hline & 0,25 & $0,25-0,10$ & $0,1-0,01$ & 0,01 & & & & & \\
\hline \multirow{2}{*}{$2522-2564$} & $0-10,0$ & $1,0-3,1$ & $25,2-11,2$ & & $7,5-14,4$ & $10,0-21,1$ & & $2,08-2,50$ & $2450-4000$ \\
\hline & 3,18 & 20,94 & 50,92 & 24,83 & 9,25 & 17,03 & 126,40 & 2,24 & 3000 \\
\hline \multirow{2}{*}{ 2956-2978 } & $0,4-3,6$ & $26,4-44,7$ & $7,6-38,9$ & $17,1-34,3$ & $6,8-7$ & $15,0-20,6$ & & $2,23-2,40$ & $3000-3400$ \\
\hline & 2,0 & 35,5 & 38,2 & 25,7 & 6,9 & 17,8 & 0,9 & 2,332 & 3200 \\
\hline \multirow{2}{*}{$3292-3348$} & $0,1-0,8$ & $0,9-45,6$ & $30,0-66,6$ & $23,7-32,3$ & $8,2-9,4$ & $9,9-22,7$ & $1-3,5$ & $2,01-2,47$ & $2400-3400$ \\
\hline & $\overline{0,6(4)}$ & $20,8(4)$ & $50,1(4)$ & $28,8(4)$ & $8,8(2)$ & $\overline{14,5(14)}$ & $\overline{2,3(2)}$ & $2,35(15)$ & $3060(18)$ \\
\hline \multirow{2}{*}{ 3804-3814 } & $1,9-9,3$ & $41,3-48,8$ & $23,6-32,6$ & $21,3-27,6$ & $6,9-10,1$ & $20,1-22,2$ & $35,6-46,4$ & $2,03-2,12$ & $2250-2600$ \\
\hline & 4,18 & 45,95 & 26,03 & 24,52 & 8,25 & 21,5 & 39,20 & 2,08 & 2450 \\
\hline \multirow{2}{*}{$3814-3982$} & $0-0,6$ & $10,0-50,0$ & $20,7-63,4$ & $15,3-28,7$ & $10,9-13,5$ & $20,0-22,1$ & $46,8-172,0$ & $2,04-2,12$ & $2550-2600$ \\
\hline & $\overline{0,3}$ & 31,8 & 48,68 & 19,95 & 111,70 & 20,68 & 122,20 & 2,09 & 2430 \\
\hline \multirow{2}{*}{$4444-4446$} & $11,8-17,6$ & $46,2-57,2$ & $14,9-30,4$ & $9,7-11,6$ & $11,8-15,1$ & $14-17$ & $17,6-20,1$ & $2,23-2,35$ & $3000-3450$ \\
\hline & 15,63 & 5057 & 23,27 & 10,53 & 13,07 & 16,0 & 18,85 & 2,24 & 3250 \\
\hline \multirow{2}{*}{$4580-4656$} & $0,5-7,5$ & $19,6-57,9$ & $22,7-69,1$ & $10,0-23,9$ & $8,9-9,9$ & $20,4-22,9$ & $0,1-95,7$ & $2,01-2,10$ & $2400-2600$ \\
\hline & 3,23 & 43,07 & 37,3 & 16,6 & 9,37 & 21,4 & 2,20 & 2,05 & 2500 \\
\hline \multirow{2}{*}{$5071-5409$} & $1,0-4,4$ & $57,4-60,0$ & $11,8-19,1$ & $19,9-26,4$ & $5,8-12,3$ & $15,8-19,0$ & $0-19,0$ & & \\
\hline & $\overline{2,70(2)}$ & $58,70(2)$ & $\overline{15,45(2)}$ & $\overline{23,15(2)}$ & $9,05(2)$ & $\overline{17,40(2)}$ & $9,5(2)$ & - & - \\
\hline \multirow{2}{*}{$5175-5232$} & $0,0-2,20$ & $7,2-31,9$ & $32,7-76,2$ & $15,3-38,4$ & $4,3-18,4$ & $5,0-20,9$ & $42,0-94,0$ & $2,08-2,28$ & $2400-2800$ \\
\hline & 1,40 & 20,76 & 45,8 & 32,32 & 9,0 & 12,26 & 59,33 & 2,18 & 2600 \\
\hline \multirow{2}{*}{$5325-5401$} & $0,04-1,3$ & $1,9-18,6$ & $37,5-65,8$ & $26,3-43,9$ & $8,2-20,7$ & $7,2-20,0$ & $0,98-2,4$ & \multirow[b]{2}{*}{-} & \multirow[b]{2}{*}{-} \\
\hline & $\overline{0,46(3)}$ & $7,31(6)$ & $\overline{54,62(6)}$ & $\overline{37,78(6)}$ & $\overline{15,80(6)}$ & $\overline{11,90(5)}$ & $1,55(5)$ & & \\
\hline \multirow[b]{2}{*}{$5660-5707$} & \multirow[b]{2}{*}{-} & $41,2-43,9$ & $33,3-47,1$ & $11,7-22,8$ & $11,9-15,0$ & $12,6-14,7$ & $156-190$ & & \multirow[b]{2}{*}{-} \\
\hline & & $\overline{42,55(2)}$ & $40,2(2)$ & $17,25(2)$ & $\overline{13,45(2)}$ & $13,65(2)$ & $173(2)$ & & \\
\hline
\end{tabular}


As a result of that, it varies within the range of 1950 $4000 \mathrm{~m} / \mathrm{s}$. The physical properties of limestone clays in the productive strata are characterized by the following parameters: density of $2.05-2.65 \mathrm{~g} / \mathrm{cm}^{3}$, porosity of $8.5-30.0 \%$, and ultrasonic wave propagation of 2100$4000 \mathrm{~m} / \mathrm{s}$. By the results of processing and interpreting the petrophysical, field and geophysical data, we can predict that some particular horizons of the productive strata have a rather high potential, i.e. the oil and gas occurrence in some of them has a bigger potential than expected. The wells drilled in all areas penetrated the complete thickness of the productive strata (3950-4000 $\mathrm{m})$ in the fields of Sangachal-Deniz and Hara-Zire Island. On the hypsometrically high-positioned local structures of Sangachal-Deniz and Duvanny-Deniz, the productive strata thickness is $2960-3600 \mathrm{~m}$.

The Alyat-Deniz oil and gas field is located in the northwest of the Baku archipelago. In that area, all suites in the productive strata have been penetrated except for the Kala suite. The productive strata deposits consist mainly of clay minerals, sandstone and siltstone. In argillaceous rock, the density is $1.90-2.20 \mathrm{~g} / \mathrm{cm}^{3}$, the porosity is $7.5-27.0 \%$, and the ultrasonic wave propagation is $1250-2200 \mathrm{~m} / \mathrm{s}$. In sandstone, the density varies within $2.14-2.48 \mathrm{~g} / \mathrm{cm}^{3}$, the porosity is $6.5-20.5 \%$, and the ultrasonic wave propagation is $1800-3000 \mathrm{~m} / \mathrm{s}$. In siltstone, the density varies within $2.06-2.45 \mathrm{~g} / \mathrm{cm}^{3}$, the porosity is $9.1-23.9 \%$, and the ultrasonic wave propagation is $1900-2100 \mathrm{~m} / \mathrm{s}$.

The permeability value determined based on core materials is relatively small. To determine changes in the dependence of this parameter on the porosity, a correlation pattern has been built. However, this relation is rather conditional. It is known that any permeable rock is porous, but not each porous rock can be permeable.

The correlation of the curves showing the changes in the studied petrophysical processes depending on the depth enabled establishing the following dependence of the porosity and permeability on the particle size distribution and carbonate content in the rock (fig. 4).

Table 4 demonstrates that until the depth is $4580 \mathrm{~m}$, the psammitic facies generally show significant growth in the particle size distribution of the rock; whereas the amount of siltstone and pellite fractions decreases, and carbonate content fluctuations remain insignificant. As a result, on the background of the insignificantly increased porosity, the permeability has grown relatively fast (up to $(122.0-185.5) 10^{-15} \mathrm{~m}^{2}$ ), which is probably due to the abovementioned change in the particle size distribution of the rock. At the same time, at a depth of 2564-3401 m, the rock is characterized by low content of the psammitic facies and increased content of the siltstone and pellite facies. It is evident that such particle size distribution causes almost zero permeability in that layer $\left((0.9-2.3) 10^{-15} \mathrm{~m}^{2}\right)$.

Then, at a depth of 3401-4580 m, a strong increase in the psammitic facies up to $66.2 \%$ and a decrease in the siltstone and pellite facies also led to a relatively steep increase in the permeability of the rock (32.2188.5) $10^{-15} \mathrm{~m}^{2}$ ). Beginning with a depth of 4580 to $4656 \mathrm{~m}$, the psammitic facies content in the rock drops to $47.3 \%$ being accompanied with a growth in the siltstone and pellite fractions and carbonate content. Such a change in the particle size distribution led to a sharp drop in permeability to $2.23 \cdot 10^{-15} \mathrm{~m}^{2}$, which can be regarded as typical for granular reservoirs [29-34].

At a depth of 4656-5109 m, the psammitic facies increase again up to $61.4 \%$ being accompanied with a relatively sharp drop in the siltstone content to $15.43 \%$ and a slight growth in the pellite fraction to $15.43 \%$. Such a combination of fractions in question led to an insignificant reduction in the porosity and a growth in the permeability just up to $9.5 \cdot 10^{-15} \mathrm{~m}^{2}$.

At a depth of 5175-5232 m, there is a sharp drop in the psammite content to $22.16 \%$, triple growth in the siltstone facies, and almost $10 \%$ growth in the pellite facies, whereas their carbonate content remains relatively low, thus leading to an increase in the permeability to $59.33 \cdot 10^{-15} \mathrm{~m}^{2}$.

Further, at a depth of 5660-5702 m, the psammitic facies content grows again up to $42.65 \%$; the siltstone content decreases to 40.02 , and there is a double reduction in the pellite fraction to just $17.35 \%$; the carbonate content grows insignificantly. As a result, when the porosity is $13.65 \%$, the rock permeability grows to $173.0 \cdot 10^{-15} \mathrm{~m}^{2}$.

The conducted analysis shows that in the studied granular reservoirs in the territory under investigation, the porosity and, especially, the permeability of the rock are mainly conditioned by the quantitative content of psammitic-and-siltstone facies and, above all, by psammitic facies. Such dependence of the rock reservoir properties is indicative of insignificant development or full absence of the secondary porosity mainly caused by fracturing and cavern porosity, etc. The low carbonate content, in its turn, excludes the probability of leaching contributing to reservoir properties of carbonate rock. The absence of such a process in the rock in question is evidenced by its low carbonate content, as well as by its low reservoir properties [35-45]. 
There is a direct relationship between the change in the rock density and the ultrasonic wave velocity; the tables show that they correlate well. However, there is no apparent relation between the lithofacies properties, reservoir properties and mentioned physical properties of the rock in this particular case.

Based on the above, we can say that to further define the oil and gas occurrence in some particular structures of the Baku archipelago, it is necessary to perform additional geological and geophysical work (gravimetric investigations, magnetometric investigations, electrometric investigations, seismic exploration and petrophysical investigations) followed by sinking deep exploratory wells in order to reveal new oil and gas accumulations.

Such activities will allow for a more detailed investigation of the reservoir properties of deep oil, gas, and water-bearing strata, and structural and tectonic aspects of the analysed areas.

\section{Conclusion}

The results of the conducted researches allow us to make the following conclusions:

- within the analysed offshore areas the change of petrophysical values in a wide range is mainly caused by the lithological heterogeneity of the assemblages, different formation depths, and structural and tectonic conditions;

- a good correlation between the porosity and permeability is conditioned by the terrigenous composition, lithofacies identity and close values of the reservoir rock porosity; the relatively high rock permeability is related to an increased content of psammitic-and-siltstone facies;

- when predicting oil and gas occurrence in deep strata of such structures, in addition to the best geophysical prospecting methods, it is necessary to take into consideration porosity and permeability properties of the rock;

Table 4

Northern areas of the Baku archipelago - the change in the particle size distribution and reservoir properties of the productive strata deposits by the depth

\begin{tabular}{|c|c|c|c|c|c|c|c|c|}
\hline \multirow{2}{*}{$\begin{array}{c}\text { Depth } \\
\text { interval, m. }\end{array}$} & \multicolumn{3}{|c|}{$\begin{array}{l}\text { Particle size distribution, \% } \\
\text { Particle size, mm }\end{array}$} & \multirow{2}{*}{$\begin{array}{l}\text { Carbonate } \\
\text { content, \% }\end{array}$} & \multirow{2}{*}{ Porosity, \% } & \multirow{2}{*}{$\begin{array}{l}\text { Permeability, } \\
10^{-15} \mathrm{~m}^{2}\end{array}$} & \multirow{2}{*}{$\begin{array}{l}\text { Density } \\
\sigma, \mathrm{g} / \mathrm{cm}^{3}\end{array}$} & \multirow{2}{*}{$\begin{array}{c}\text { Ultrasonic } \\
\text { wave } \\
\text { propagation, } \\
V, \mathrm{~m} / \mathrm{s}\end{array}$} \\
\hline & $>0,25-0,1$ & $0,1-0,01$ & $<0,01$ & & & & & \\
\hline $2522-2564$ & 01020300405060070 & $\stackrel{0102030405060070}{0}$ & 뇨 & $\stackrel{1}{0}^{10} \quad 20$ & $\begin{array}{lllll}0 & 10 & 20 & 30 \\
\end{array}$ & $\underbrace{0.50100150200}$ & $2 \quad 2,2,2,42,6$ & $\begin{array}{llll}2000 & 3000 & 4000\end{array}$ \\
\hline $2956-2978$ & & & & & & & & \\
\hline $3292-3318$ & & & & & & & & \\
\hline $3325-3401$ & & & & & & & & $i$ \\
\hline $3804-3814$ & & & & & & & $i^{\prime}$ & $i$ \\
\hline $3814-3982$ & & & & & & & & \\
\hline $4444-4446$ & & 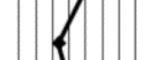 & & & & & & \\
\hline $4580-4656$ & & $t$ & & & & & & 4 \\
\hline $5071-5109$ & & & & & $f$ & & $!$ & \\
\hline $5175-5232$ & & & $>$ & & & & + & b \\
\hline $5660-5707$ & & & 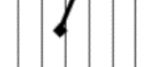 & 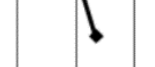 & 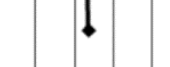 & & & \\
\hline
\end{tabular}


- the change in the rock density and ultrasonic wave velocity depending on the depth signifies their good correlation and the absence of such correlation between them and the rock reservoir properties, which mainly indicates that the secondary porosity is not characteristic for the reservoir rock.

\section{References}

1. Ali-Zade A.A., Akhmedov G.A., Akhmedov A.M., Aliev A.K., Zeinalov M.M. Geologiia neftianykh i gazovykh mestorozhdenii azerbaidzhana [Geology of oil and gas fields of Azerbaijan]. Moscow, Nedra, $1966,390 \mathrm{p}$.

2. Rakhmanov R.R. Zakonomernosti formirovaniia i razmeshcheniia zon neftegazonakopleniia $\mathrm{v}$ mezozoiskikh otlozheniiakh Azerbaidzhana [Patterns of formation and placement of oil and gas accumulation zones in the Mesozoic deposits of Azerbaijan]. Baku, Elm, 1985, 108 p.

3. Kerimov K.M., Rakhmanov R.R., Kheirov M.B. Neftegazonosnost Iuzhno-Kaspiiskoi megavpadiny [Oil and gas potential of the South Caspian megawall]. Baku, 2001, 317 p.

4. Kerimov K.M. Glubinnoe stroenie i neftegazonosnost depressionnykh zon Azerbaidzhana i Iuzhnogo Kaspiia [The deep structure and oil and gas potential of the depressed zones of Azerbaijan and the South Caspian]. Baku, 2009, 438 p.

5. Khain V.E. Tektonika neftegazonosnykh oblastei iugo-vostochnogo pogruzheniia Bolshogo Kavkaza [Tectonics of the oil and gas bearing areas of the southeast submergence of the Greater Caucasus]. Moscow, Gostoptekhizdat, 1958, 224 p.

6. Lebedev T.S. Model studies of physical properties of mineral matter in high pressure temperature experiments. Phys. Earth and Planet. Inter., 1980, vol. 25, pp.292-303. DOI: 10.1016/0031-9201(80)90126-0

7. Mekhtiev U.Sh., Kheirov M.B. Litologopetrograficheskie osobennosti i kollektorskie svoistva porod kalinskoi i podkirmakinskoi svit Apsheronskoi neftegazonosnoi oblasti Azerbaidzhana [Lithological and petrographic features and reservoir properties of rocks of the Kalinsky and Podkirmakinsky suites of the Absheron oil and gas region of Azerbaijan]. Baku, 2007, part 1, $238 \mathrm{p}$.

8. Spravochnik po litologii [Lithology Handbook]. Ed. N.B. Vassoevich. Moscow, 1988, 509 p.

9. Gurbanov V.Sh., Sultanov L.A., Samed-Zade A.A. et al. Geologicheskoe stroenie mestorozhdeniia Neft
Dashchlary i analiz zakonomernykh izmenenii kollektorskikh svoistv porod produktivnoi tolshchi zavisimosti ot glubiny [Geological structure of the Neft Dashchlary field and analysis of regular changes in the reservoir properties of rocks of the productive strata depending on depth]. Республика Казахстан, 2016, no.3-4 (47-48), pp.23-30.

10. Sostavlenie kataloga kollektorskikh svoistv mezokainozoiskikh otlozhenii mestorozhdenii nefti i gaza i perspektivnykh struktur Azerbaidzhana: otchet Nauchno-issledovatelskogo instituta geofiziki 105-2009 [Compilation of the catalog of the reservoir properties of the Mesozoic Cenozoic deposits of oil and gas fields and prospective structures of Azerbaijan: report of the Research Institute of Geophysics - 105-2009]. Fondy upravleniia geofiziki i geologii. Baku, 2010.

11. Kocharli Sh.S. problemy voprosy neftegazovoi geologii Azerbaidzhana [Problems issues of oil and gas geology of Azerbaijan]. Baku, 2015, 278 p.

12. Gurbanov V.Sh., Sultanov L.A., Valiyev S.A., Babaeva M.T. The lithophysical and collector characteristics of mesozoic-cenozoic deposits of north-western part of the Caspian depression. Perm Journal of Petroleum and Mining Engineering, 2015, no.17, pp. 5-15. DOI: 10.15593/2224-9923/2015.17.1

13. Uspenskaia N.Iu., Tauson N.N. Neftegazonosnye provintsii i oblasti zarubezhnykh stran [Oil and gas provinces and regions of foreign countries]. Moscow, Nedra, 1972, 283 p.

14. Gurbanov V.Sh., Sultanov L.A. On oil-and-gas content of Mesozoic deposits in Azerbaijan. Perm Journal of Petroleum and Mining Engineering, 2015, no.16, pp.7-13. DOI: 10.15593/2224-9923/2015.16.1

15. Hasanov A.B., Balakishibayli Sh.A. The influence of recent geodynamics on the physicomechanical state of the geological environment of the sedimentary cover. Evaluation of synthetic elastic parameters of reservoirs, fluid phase saturation and temperatures in the depths. Materials of International Workshop. Baku, 2010, pp. 101-108.

16. Hasanov A.B., Melikov Kh.F. 3D model of productive layers according to data geophysics and petrophysics. The influence of recent geodynamics on the physic-mechanical state of the geological environment of the sedimentary cover. Materials of International Workshop. Baku, 2010, pp.101-108.

17. Aliyarov R.Y., Hasanov A.B., Aslanzade F.B., Samedzade A.A. Recognition of fluid flow zones in oil reservoirs by loq methods. Azerbayjan Geologist, 2018, no.22, pp.121-128. 
18. Ali-Zade A.A., Salaev S.G., Aliev A.I. Nauchnaia otsenka perspektiv neftegazonosnosti Azerbaidzhana i Iuzhnogo Kaspiia i napravlenie poiskovo-razvedochnykh rabot [Scientific assessment of the oil and gas prospects of Azerbaijan and the South Caspian and the direction of exploration]. Baku, Elm, 1985, 227 p.

19. Landolt-Bornstein tables. Physical properties of rocks. Ed. G. Argenheisen. New York, 1983, vol.V.

20. Theoretical and experimental investigations of physical properties of rocks and minerals under extreme p,T-conditions. Berlin, Academie Verlag, $1979,232 \mathrm{p}$.

21. Afandiyeva M.A., Guliyev I.S. Maicop Group-shale hydrocarbon complex in Azerbaijan. 75 EAGE Conference and Exhibition. London, 2013, pp.06-13. DOI: 10.3997/2214-4609.20130979

22. Salmanov A.M., Suleimanov A.M, Magerramov B.I. paleogeologiia neftegazonosnykh raionov Azerbaidzhana [Paleogeology of oil and gas regions of Azerbaijan]. Baku, 2015, 470 p.

23. Kerimov K.M. Glubinnoe stroenie i neftegazonosnost depressionnykh zon Azerbaidzhana i Iuzhnogo Kaspiia [The deep structure and oil and gas potential of the depressed zones of Azerbaijan and the South Caspian]. Baku, 2009, 438 p.

24. Fizicheskie svoistva gornykh porod i poleznykh iskopaemykh [Physical properties of rocks and minerals]. Ed. N.B.Dortman. Moscow, Nedra, 1976, $527 \mathrm{p}$.

25. Kozhevnikov D.A. Petrofizicheskaia invariantnost granuliarnyh kollektorov [Petrophysical Invariance of Granular Reservoirs]. The Russian Geophysics Journal, 2001, no.4, pp.31-37.

26. Babaev M.S. Kollektorskie parametry porod vybrosov griazevykh vulkanov Bakinskogo arkhipelaga (na primere o. Duvanny i o. Bulla) [Mud volcanoes emission rock Keservoir parameters Baku archipelago (for example, island Duvanny and island Bull)]. Tematicheskii sbornik nauchnykh trudov. Baku, Izdatelstvo Azerbaidzhanskogo IU, 1991, pp.82-84.

27. Spravochnik po geologii nefti i gaza [Handbook of geology of oil and gas]. Moscow, Nedra, 1988, 480 p.

28. Gurbanov V.Sh., Hasanov A.B., Sultanov L.A. Physical characteristics and filtration capacitance properties (FCP) of prospective oil and gas bearing horizons in the lower levels of Productive thickness (PT) in the land area of Azerbaijan. Modern problems of innovative technologies in oil and gas production and applied mathematics: International conference dedicated to the 90th anniversary of academician AZAD MIRZAJANZADE. Baku, 2018, pp.418-419.

29. Sultanov L.A. Geologicheskie i kollektorskie svoistva otlozhenii produktivnoi tolshchi ploshchadi Kalamaddin V predelakh Prikurinskoi neftegazonosnoi mezhgornoi vpadiny [Geological and reservoir properties of sediments in the productive strata of the Kalamaddin area within the Prikurinsky oil and gas bearing intermountain basin]. Respublika Kazakhstan, 2018, no.3 (55), pp.25-31.

30. Sultanov L.A. The collector characteristics of mesozoic-cenozoic deposits of north-west part of south Caspian Basin. Modern problems of innovative technologies in oil and gas production and applied mathematics: International conference dedicated to the 90th anniversary of academician AZAD MIRZAJANZADE. Baku, 2018, pp.561-563.

31. Narimanov N.R. geodinamicheskie aspekty formirovaniia osadochnogo chekhla IuzhnoKaspiiskoi vpadiny [Geodynamic aspects of the formation of sedimentary cover of the South Caspian basin]. Geologiia nefti i gaza, 2003, no.6, pp.26-31.

32. Rachinskii M.Z., Chilingar Dzh. Rezultaty geologo-razvedochnykh rabot 1990-2005 gg., geologicheskie aspekty perspektiv i kolichestvennaia otsenka [Results of geological exploration 19902005, geological aspects of prospects and quantitative assessment]. Zhurnal ANKh, 2007, no.1, pp.7-15.

33. Volarovich M.P., Baiuk E.I., Eefimova G.A. Uprugie svoistva mineralov pri vysokikh davleniiakh [Elastic properties of minerals at high pressures]. Moscow, Nauka, 1975, 130 p.

34. Sultanov L.A., Narimanov N.R., Samadzadeh A.A. The geological structure of the Neft Dashlari deposit and the analysis of the regularity of the change in the reservoir properties of the productive floor rocks, depending on the depth of their occurrence. EUREKA: Physical Sciences and Engineering, 2019, no.1, pp.55-62.

35. Sultanov L.A. Geologo-petrofizicheskie osobennosti glubokozalegaiushchikh kollektorov neftegazonosnykh ploshchadei mestorozhdeniia severo-zapadnoi chasti Iuzhno-Kaspiiskoi vpadiny [Geological and petrophysical features of deep-seated reservoirs of oil and gas bearing deposits in the northwestern part of the South Caspian depression]. Respublika Kazakhstan, 2019, no.1(56), pp.22-25. 
36. Sokolov B.A. Evoliutsiia i neftegazonosnost osadochnykh basseinov [Evolution and oil and gas potential of sedimentary basins]. Moscow, Nauka, $1980,243 \mathrm{p}$.

37. Gadirov V.G. Magmaticheskii vulkanizm srednekurinskoi vpadiny Azerbaidzhana i ego rol v skoplenii uglevodorodov [Magmatic volcanism of the central Kura basin of Azerbaijan and its role in the accumulation of hydrocarbons]. Educatio, 2001, III (10), pp.64-69.

38. Gadirov V.G. Prognozirovanie vulkanogennykh obrazovanii mezozoia Srednekurinskoi depressii i ikh neftegazonosnosti po kompleksnym geofizicheskim dannym [Prediction of Mesozoic volcanogenic formations of the Srednekurinsky depression and their oil and gas potential according to complex geophysical data]. Abstract of Ph. D. thesis. Baku, 1991, 22 p.

39. Gurbanov V.Sh., Sultanov L.A.,, Shykhyev N.G. O neftegazonosnosti mezozoiskikh otlozhenii Azerbaidzhana [On the oil and gas potential of the Mesozoic deposits of Azerbaijan]. Novye idei $v$ naukakh o zemle: Materialy XIV Mezhdunarodnoi konferentsii. Rossiiskii gosudarstvennyi geologorazvedochnyi universitet imeni Sergo Ordzhonikidze. Moscow, 2019, vol.V, pp.47-50.

40. Sultanov L.A. Geologicheskoe stroenie i rezultaty petrofizicheskikh issledovanii neftegazonosnykh ploshchadei mestorozhdeniia severozapadnoi chasti Iuzhno-Kaspiiskoi vpadiny [Geological structure and results of petrophysical studies of oil and gas bearing fields in the northwestern part of the South Caspian basin]. Bulatovskie chteniia. III Mezhdunarodnaia nauchnoprakticheskaia konferentsiia. Krasnodar, 2019.

41. Gasanov A.B., Sultanov L.A. Geologopetrofizicheskie osobennosti kollektorov mestorozhdenii Bakinskogo arkhipelaga [Geological and petrophysical features of reservoirs in the Baku archipelago]. Izvestiia vysshikh tekhnicheskikh uchebnykh zavedenii Azerbaidzhana, 2018, no.3, pp.7-16.

42. Physical properties of the mineral system of the Earth's interior: International monograph Project 3 CAPG. Praha, 1985.

43. Akhmedov A.M. O geologicheskoi kharakteristike i perspektivakh neftegazonosnosti ploshchadi Umid [About the geological characteristics and prospects of oil and gas potential of the Umid area]. Azerbaidzhanskoe neftianoe khoziaistvo, 2008, no.3, pp.19-22.
44. Babazade B.Kh., Putkaradze L.A. O poiskakh zalezhei gaza i nefti $\mathrm{v}$ pribrezhnoi morskoi zone Apsheronskogo poluostrova i Bakinskogo arkhipelaga [On the search for gas and oil deposits in the coastal marine zone of the Absheron peninsula and the Baku archipelago]. Oil and Gas Geology, 1961, no.10, pp.7-11.

45. Gurbanov V.Sh., Narimanov N.R., Sultanov L.A., Babaev M.S. Geologicheskoe stroenie i kollektorskie svoistva mezokainozoiskikh otlozhenii DzharlySaatlinskogo neftegazonosnogo raiona na bolshikh glubinakh [Geological structure and reservoir properties of the Mesozoic Cenozoic sediments of the Jarly-Saatli oil and gas region at great depths]. Izvestiia Uralskogo gosudarstvennogo gornogo universiteta, 2016, no.2 (42), pp.25-27. DOI: 10.21440/2307-2091-2016-2-25-27

\section{Библиографический список}

1. Геология нефтяных и газовых месторождений Азербайджана / А.А. Али-заде, Г.А. Ахмедов, А.М. Ахмедов, А.К. Алиев, М.М. Зейналов. - М.: Недра, 1966. - 390 с.

2. Рахманов Р.Р. Закономерности формирования и размещения зон нефтегазонакопления в мезозойских отложениях Азербайджана. - Баку: Элм, 1985. - $108 \mathrm{c}$.

3. Керимов К.М., Рахманов Р.Р., Хеиров М.Б. Нефтегазоносность Южно-Каспийской мегавпадины. - Баку, 2001. - 317 с.

4. Керимов К.М. Глубинное строение и нефтегазоносность депрессионных зон Азербайджана и Южного Каспия. - Баку, 2009. - 438 с.

5. Хаин В.Е. Тектоника нефтегазоносных областей юго-восточного погружения Большого Кавказа. - М.: Гостоптехиздат, 1958. - 224 с.

6. Lebedev T.S. Model studies of physical properties of mineral matter in high pressure temperature experiments // Phys. Earth and Planet. Inter. - 1980. - Vol. 25. - P. 292-303. DOI: $10.1016 / 0031-9201(80) 90126-0$

7. Мехтиев У.Ш., Хеиров М.Б. Литологопетрографические особенности и коллекторские свойства пород калинской и подкирмакинской свит Апшеронской нефтегазоносной области Азербайджана. - Баку, 2007. - Ч. 1. - 238 с.

8. Справочник по литологии / под ред. Н.Б. Вассоевича. - М., 1988. - 509 с.

9. Геологическое строение месторождения Нефт Дашлары и анализ закономерных изменений 
коллекторских свойств пород продуктивной толщи в зависимости от глубины / В.Ш. Гурбанов, Л.А. Султанов, А.А. Самед-заде [и др.] // Республика Казахстан. - 2016. - № 3-4 (47-48). C. 23-30.

10. Составление каталога коллекторских свойств мезокайнозойских отложений месторождений нефти и газа и перспективных структур Азербайджана: отчет Научно-исследовательского института геофизики - 105-2009 / Фонды Управления геофизики и геологии. - Баку, 2010.

11. Кочарли Ш.С. Проблемы и вопросы нефтегазовой геологии Азербайджана. - Баку, 2015. - 278 c.

12. Литолого-петрографические и коллекторские характеристики мезокайнозойских отложений северо-западной части Южно-Каспийской впадины / В.Ш. Гурбанов, Л.А. Султанов, С.А. Валиев, М.Т. Бабаева // Вестник Пермского национального исследовательского политехнического университета. Геология. Нефтегазовое и горное дело. - 2015. № 17. - C. 5-15. DOI: 10.15593/2224-9923/2015.17.1

13. Успенская Н.Ю., Таусон Н.Н. Нефтегазоносные провинции и области зарубежных стран. - М.: Недра, 1972. -283 с.

14. Гурбанов В.Ш., Султанов Л.А. О нефтегазоносности мезозойских отложений Азербайджана // Вестник Пермского национального исследовательского политехнического университета. Геология. Нефтегазовое и горное дело. - 2015. № 16. - C. 7-13. DOI: 10.15593/2224-9923/2015.16.1

15. Hasanov A.B., Balakishibayli Sh.A. The influence of recent geodynamics on the physicomechanical state of the geological environment of the sedimentary cover // Evaluation of synthetic elastic parameters of reservoirs, fluid phase saturation and temperatures in the depths: Materials of International Workshop. - Baku, 2010. - P. 101-108.

16. Hasanov A.B., Melikov Kh.F. 3D model of productive layers according to data geophysics and petrophysics // The influence of recent geodynamics on the physic-mechanical state of the geological environment of the sedimentary cover: Materials of International Workshop. - Baku, 2010. - P. 101-108.

17. Recognition of fluid flow zones in oil reservoirs by loq methods / R.Y. Aliyarov, A.B. Hasanov, F.B. Aslanzade, A.A. Samedzade // Azerbayjan Geologist. - 2018. - № 22. - P. 121-128.

18. Али-Заде А.А., Салаев С.Г., Алиев А.И. Научная оценка перспектив нефтегазоносности
Азербайджана и Южного Каспия и направление поисково-разведочных работ. - Баку: Элм, 1985. $-227 \mathrm{c}$.

19. Landolt-Bornstein tables. Physical properties of rocks / ed. G. Argenheisen. - New York, 1983. - Vol. V.

20. Theoretical and experimental investigations of physical properties of rocks and minerals under extreme p,T-conditions. - Berlin: Academie Verlag, 1979. - $232 \mathrm{p}$.

21. Afandiyeva M.A., Guliyev I.S. Maicop group-shale hydrocarbon complex in Azerbaijan // 75 EAGE Conference and Exhibition. - London, 2013. - P. 06-13. DOI: 10.3997/2214-4609.20130979

22. Салманов А.M., Сулейманов А.M, Магеррамов Б.И. Палеогеология нефтегазоносных районов Азербайджана. - Баку, 2015. - 470 с.

23. Керимов К.М. Глубинное строение и нефтегазоносность депрессионных зон Азербайджана и Южного Каспия. - Баку, 2009. -438 c.

24. Физические свойства горных пород и полезных ископаемых / под ред. Н.Б. Дортман. М.: Недра, 1976. -527 с.

25. Кожевников Д.А. Петрофизическая инвариантность гранулярных коллекторов // Геофизика. 2001. - № 4. - C. 31-37.

26. Бабаев М.С. Коллекторские параметры пород и выбросы грязевых вулканов Бакинского архипелага (на примере о. Дуванны и о. Булла) // Тематический сб. науч. тр. - Баку: Изд-во Азербайджанского ИУ, 1991. - С. 82-84.

27. Справочник по геологии нефти и газа. М.: Недра, 1988. - 480 с.

28. Gurbanov V.Sh., Hasanov A.B., Sultanov L.A. Physical characteristics and filtration capacitance properties (FCP) of prospective oil and gas bearing horizons in the lower levels of Productive thickness (PT) in the land area of Azerbaijan // Modern problems of innovative technologies in oil and gas production and applied mathematics: International conference dedicated to the 90th anniversary of academician AZAD MIRZAJANZADE. - Baku, 2018. - C. 418-419.

29. Султанов Л.А. Геологические и коллекторские свойства отложений продуктивной толщи площади Каламаддин в пределах Прикуринской нефтегазоносной межгорной впадины // Республика Казахстан. - 2018. - № 3 (55). - C. 25-31.

30. Sultanov L.A. The collector characteristics of mesozoic-cenozoic deposits of north-west part of south Caspian Basin // Modern problems of innovative 
technologies in oil and gas production and applied mathematics: International conference dedicated to the 90th anniversary of academician AZAD MIRZAJANZADE. - Baku, 2018. - P. 561-563.

31. Нариманов Н.Р. Геодинамические аспекты формирования осадочного чехла Южно-Каспийской впадины // Геология нефти и газа. - 2003. № 6. - С. 26-31.

32. Рачинский М.3., Чилингар Дж. Результаты геолого-разведочных работ 1990-2005 гг., геологические аспекты перспектив и количественная оценка // Журнал АНХ. - 2007. - № 1. - С. 7-15.

33. Воларович М.П., Баюк Е.И., Еэфимова Г.А. Упругие свойства минералов при высоких давлениях. - М.: Наука, 1975. - 130 с.

34. Sultanov L.A., Narimanov N.R., Samadzadeh A.A. The geological structure of the Neft Dashlari deposit and the analysis of the regularity of the change in the reservoir properties of the productive floor rocks, depending on the depth of their occurrence // EUREKA: Physical Sciences and Engineering. 2019. - № 1. - C. 55-62.

35. Султанов Л.А. Геолого-петрофизические особенности глубокозалегающих коллекторов нефтегазоносных площадей месторождения северозападной части Южно-Каспийской впадины, Республика Казахстан // Горно-геологический журнал. - 2019. - № 1 (56). - С. 22-25.

36. Соколов Б.А. Эволюция и нефтегазоносность осадочных бассейнов. - М.: Наука, 1980. - 243 с.

37. Гадиров В.Г. Магматический вулканизм среднекуринской впадины Азербайджана и его роль в скоплении углеводородов // Educatio. 2001. - III (10). - C. 64-69.

38. Гадиров В.Г. Прогнозирование вулканогенных образований мезозоя Среднекуринской депрессии и их нефтегазоносности по комплексным геофизическим данным: автореф. дис. ... канд. геол.-мин. наук. - Баку, 1991. - 22 с.
39. Гурбанов В.Ш., Султанов Л.А., Шыхыев Н.Г. O нефтегазоносности мезозойских отложений Азербайджана // Новые идеи в науках о Земле: материалы XIV Междунар. конф. / Российский государственный геолого-разведочный университет имени Серго Орджоникидзе. - М., 2019. T. V. - C. $47-50$.

40. Султанов Л.А. Геологическое строение и результаты петрофизических исследований нефтегазоносных площадей месторождения северо-западной части Южно-Каспийской впадины // Булатовские чтения: III Междунар. науч.-практ. конф. / Кубанский государственный технологический университет. - Краснодар, 2019.

41. Гасанов А.Б., Султанов Л.А. Геологопетрофизические особенности коллекторов месторождений Бакинского архипелага // Известия высших технических учебных заведений Азербайджана. - 2018. - № 3. - С. 7-16.

42. Physical properties of the mineral system of the Earth's interior: International monograph Project 3 CAPG. - Praha, 1985.

43. Ахмедов А.М. О геологической характеристике и перспективах нефтегазоносности площади Умид // Азербайджанское нефтяное хозяйство. - 2008. - № 3. - С. 19-22.

44. Бабазаде Б.Х., Путкарадзе Л.А. O поисках залежей газа и нефти в прибрежной морской зоне Апшеронского полуострова и Бакинского архипелага // Геология нефти и газа. 1961. - № 10. - C. 7-11.

45. Геологическое строение и коллекторские свойства мезокайнозойских отложений Джарлы-Саатлинского нефтегазоносного района на больших глубинах / В.Ш. Гурбанов, Н.Р. Нариманов, Л.А. Султанов, М.С. Бабаев // Известия Уральского государственного горного университета. - 2016. - № 2 (42). - C. 25-27. DOI: $10.21440 / 2307-2091-2016-2-25-27$

Please cite this article in English as:

Gurbanov V.Sh., Sultanov L.A. Petrophysical aspects of deep reservoirs in the Absheron and Baku Archipelagos. Perm Journal of Petroleum and Mining Engineering, 2019, vol.19, no.3, pp.204-215. DOI: 10.15593/2224-9923/2019.3.1

Просьба ссылаться на эту статью в русскоязычных источниках следующим образом:

Гурбанов В.Ш., Султанов Л.А. Петрофизические особенности глубокозалегающих коллекторов Апшеронского и Бакинского архипелагов // Вестник Пермского национального исследовательского политехнического университета. Геология. Нефтегазовое и горное дело. - 2019. - Т.19, №3. - С.204-215. DOI: 10.15593/2224-9923/2019.3.1 